\title{
Economic and Social Impacts of COVID 19 on National Economies from the Point of View of Economic Theory
}

\author{
Miloš Nový ${ }^{1, *}$, and Čestmír Jarý ${ }^{1}$ \\ ${ }^{1}$ University of West Bohemia, Faculty of Economics, Department of Economics and Quantitative \\ Methods, Univerzitní 8, 30614 Pilsen, Czech Republic
}

\begin{abstract}
.
Research background: The world economy is currently affected by the devastating effects of the global COVID 19 pandemic, reaching the Great Depression of the 1930s. The economic policies of the affected countries are currently focused on short-term measures on the aggregate demand side. To this end, the growth of the public finance deficit is being prepared in the area of fiscal policy, which will ultimately deepen the indebtedness of national economies. If this economic policy is to be sustainable in the long term, measures on the aggregate demand side must be accompanied by measures on the aggregate supply side.

Purpose of the article: The purpose of this article is to determine how the current globalization processes affecting the supply and demand sides of selected national economies will be affected in the short and long term as a result of the global COVID 19 pandemic.

Methods: A description of the AS - AD model will be performed, covering both short and long periods, and then a description of the impact of globalization processes on aggregate supply and aggregate demand. This will be followed by an analysis of the expected economic and social impacts of COVID 19 on individual globalization processes affecting the supply and demand sides of selected national economies and economic units.

Findings \& Value added: The article will help to find a systemic approach to the recovery of national economies affected by the effects of the global pandemic COVID 19 through the prism of the AS - AD model.
\end{abstract}

Keywords: globalization; aggregate demand; aggregate supply; economic policy; economic growth

JEL Classification: $E 60 ; F 43 ; F 62 ; F 68$

${ }^{*}$ Corresponding author: novym $@$ kem.zcu.cz 


\section{Introduction}

Due to the introduction of anti-epidemiological measures in individual national economies, the world economy is currently going through the largest economic slump after World War II, comparable to the Great Depression of the 1930s, because of the COVID coronavirus epidemic. One of the possibilities offered by the economic theory in examining various factors affecting individual national economies is the use of the AS-AD model which analyses the examined factors according to whether they affect the supply or demand side of economies. This model also takes into account the fact whether the factors under consideration act in the short or long term.

In the current period, we are witnessing how individual national governments and central banks respond to the above-mentioned decline in macroeconomic output through their short-term demand-oriented stabilisation policies. The proof is a significant loosening of fiscal and monetary criteria, which was impossible in previous decades. The expansionary fiscal policies result in the increase in the public finance deficit deepening the already considerable indebtedness of individual national economies. Expansionary monetary policies result in the strengthening of inflationary pressures through the growth in money stock and the decline in interest rates. In order that these demand-side stabilisation policies do not to lead to a macroeconomic imbalance, they must be accompanied by measures on the aggregate supply side in the medium and long term.

It is obvious that all the measures of national governments and central banks take place in an environment of a highly globalized world economy, where individual national authorities have significantly limited room to maneuver. The subject of this paper is to analyse the impact of COVID on globalization processes affecting the supply and demand sides of individual national economies.

The first part of the paper will describe the AS-AD model, covering both short and long periods. The second part will deal with the impact of globalization processes on aggregate supply and aggregate demand. The third part of the paper will analyse the expected effects of COVID on individual globalization factors affecting the supply and demand sides of selected national economies and economic units. The article will contribute to finding a systemic approach to the recovery of national economies affected by the effects of the COVID-19 global pandemic through the prism of the AS-AD model.

\section{AS-AD model}

One of the ways how to analyse the development of macroeconomic variables such as the real product, employment or price levels in the short and long term is to use the macroeconomic model of aggregate supply and aggregate demand (hereinafter the AS-AD model).

In accordance with the established economic theory [e.g. 1-3], the aggregate supply (AS) represents the level of real product that companies would produce and be willing to sell at a given price. The growing form of short-run aggregate supply (SRAS) is based on the misperceptions theory (M. Friedman, R. Lucas), the sticky-wage theory (J. M. Keynes) and the sticky-price theory. The long-run aggregate supply (LRAS), which depends on the amount of labour, capital stock, and the technology level and availability, has a form of vertical at the level of potential product $\left(\mathrm{Y}^{*}\right)$. The short-run aggregate supply may rise due to a decrease in real wages, expected inflation, raw material prices, etc. The long-run aggregate supply increases if the amount of labour and the volume of human capital in the economy grow, work incentives are strengthened, new deposits of raw materials are 
discovered, capital stock levels are growing, new techniques and technologies are being developed, climatic conditions are improving, etc. In these cases, the growth of the long-run aggregate supply is simultaneously accompanied by the growth of the short-run aggregate supply. Supply shocks can be divided from several perspectives - domestic and external, one-off and permanent, in the field of internationally traded goods and non-traded goods, reducing or, conversely, not reducing the efficiency of production factors [4].

The aggregate demand (AD) expresses how large a real product would be purchased at a given price level. The declining nature of the $\mathrm{AD}$ curve is caused by the effect of real money balances (the Pigou effect), the effect of real interest rates (the Keynes effect) and the effect of international trade (the Mundell Fleming effect). The total amount of demanded real product is the sum of household consumption expenditure $(\mathrm{C})$, corporate investment expenditure (I), government purchases (G), and net exports (NX). Factors affecting the growth of aggregate demand include, among others, a growth in nominal money stock, disposable income and household wealth, population growth, a change in the expected inflation, a decline in corporate tax burden, a decline in interest rates, a growth in government purchases and transfers, an increase in foreign product, a change in nominal exchange rate, etc.

By connecting the curves of aggregate supply and aggregate demand, we get the point of macroeconomic equilibrium (E0), see Figure 1a.
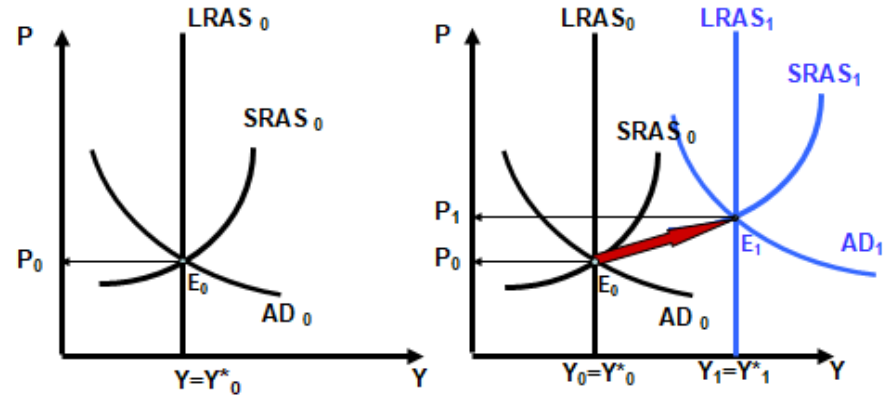

Fig. 1a, b. AS-AD model.

Source: own based

\section{The impact of globalization processes on aggregate supply and aggregate demand}

In assessing the impact of globalization processes on aggregate supply and aggregate demand, it is necessary to first define the very concept of globalization. The problem is that many domestic and international authors approach the concept of globalization in completely different ways [e.g. 5-7]. Breinek [5] describes globalization as "... a growing integration of economic activities through individual markets." Historically, he distinguishes three waves of globalization. He associates the first wave of globalization (2nd half of the 19th century to 1914) with a marked decrease in transport costs, with the progress in communication devices and with reducing trade barriers. On the contrary, the interwar period (1914 - 1945) is characterized by protectionism caused by the deteriorating economic situation in individual national states. The renewal of trade barriers resulted in economic stagnation or a considerable decline in the dynamics of economic growth. The negative experience of the interwar period led to the second wave of globalization (1945 1980) with a strong pressure on internationalisation consisting in the expansion of economic activities beyond national borders. Institutionally, internationalisation has been backed by the emergence of supranational organisations such as the World Bank, the 
International Monetary Fund, GATT/WTO, etc. The trade barriers from the interwar period have been removed. Even in the second wave of globalization, transport costs were further reduced, and technological progress was growing. The current third wave of globalization is characterized by the existence of new 24-hour-per-day interconnected markets of goods, services and capital, by the use of new communication tools such as the Internet or smartphones, by the strong role of new players, for example, transnational corporations and regional blocs such as EU, G7, OECD, etc., and finally, by the existence of new rules and standards such as deregulation, privatization, etc. Kunešová [6] consider globalization to be the processes that are represented by the considerable increase in international flows of capital, goods, services, information, and people, including the growing number and power of transnational corporations. Žídek [7] works with two approaches of opinion. The first approach, which, among others, Jeníček [8] advocates, associates globalization with current qualitative changes, which are related to advances in information and communication technologies, as well as with the process of transnationalisation based on the growing influence of transnational corporations. The second approach, advocated by, for example Kocourek, Bednářová and Laboutková [9], grasps globalization as further continuation of integration tendencies consisting in "...the opening and integration of markets of goods, services, capital and labour in space and time." The importance of labour markets is underlined by Hejduková and Kureková [10] who emphasise the global migration of human resources in the context of globalization.

If, according to Woodward [11] who considers economic globalization to be a decisive phenomenon of the entire globalization process, we focus our attention in this direction, then the globalized economy covers the single world market. It is a natural economic process that is based on a functioning market mechanism built on the principle of the invisible hand of the market. However, it is naturally also affected by non-economic factors such as political decisions. It is a process of expansion of national economic entities in various forms in foreign countries in order to find more space to increase revenues and reduce costs, which results in the emergence of the international market. A similar view is given by Janáček [12], who talks about the growing involvement of the "third world", especially the developing countries of Southeast Asia, in the world economy and world trade, as well as in the world financial markets. This fact has been made possible both by the internal development of these countries and by the removal of transport, information, customs and other barriers that hindered globalization, namely with the significant development of multinational corporations.

At the same time, the preconditions that initiated and enabled the emergence of globalization processes determine the above-mentioned definitions of the globalization concept. They are technical, institutional, and economic preconditions.

The technical preconditions relate to the creation of sufficient, economically substantiated transport capacity. Its development began with the construction of the unified railway network in the 19th century, followed by the use of motor water transport and later the road network. After World War II, air transport also played an important role. The transfer of information can also be included in the technical preconditions, as trade is not possible without mutual exchange of information. The global market does not require physical contact among economic agents but creates an enormous pressure on the transfer of current information. The whole process is now completed by creating the worldwide Internet network, which also allows the employment of smartphones. This is related to the current electronic banking, which has significantly strengthened foreign trade in goods and services.

Institutional preconditions are related to the pressure of the private sector, which forces national governments to change their view of foreign economic relations. The medieval economic autarchy is gradually being replaced by the liberalization of these foreign 
economic relations. However, this trend is a highly political issue, which is why liberalization tendencies are repeatedly replaced by state interventionism, for example in times of economic crisis. After World War II, the efforts of national governments to promote liberalization have been supported by the establishment of world organisations, such as the World Trade Organisation (WTO), the International Monetary Fund (IMF), etc.

Economic preconditions consist in the accumulation of a sufficient supply of capital, which can no longer be effectively used in the domestic environment and allows either to gain positions in the form of building new own capacities in foreign countries or purchasing majority interests abroad. The result is the emergence of large transnational corporations. If these entities begin to considerably influence economic as well as political processes, we can call this trend transnationalisation, which has been significantly accelerated by the system of investment incentives. On the other hand, the same investment incentives contribute to the distortion of the market environment, including a fundamental change in the economic structure of the host country, for example by the emergence of a monocultural environment. It follows from the above-mentioned facts that the decline in transport costs and the development of information technologies, liberalization, internationalisation and transnationalization are the most important preconditions that have enabled the process of globalization.

If we approach the analysis of supply and demand side of the economy through the prism of globalization preconditions and globalization consequences, it is obvious that the technical preconditions primarily affect the supply side of the economy. The technical preconditions are primarily related to production costs. Therefore, it can be stated that the global market arose precisely as a result of the effort to substantially reduce costs, both direct ones, i.e. production costs, and indirect ones, i.e opportunity costs. In the context of globalization, a functioning, sufficiently capacity-oriented transport network has been created, which is at the same time supported by an efficient logistics system. The mentioned transport network serves not only for the transport of goods, but also for the transport of capital goods, when these can be obtained all over the world, while the transport possibilities make it possible to transport even the heaviest machines. The cheapest raw materials from all over the world are available to individual companies. A further decline in costs has been caused by the significant reduction in the necessary stock of raw materials, semi-finished products, and finished products. The globalized economy has thus enabled the emergence and functioning of a "just in time" system. Of course, reducing the amount of stock levels has led to a reduction in the cost of storage space and the cost of servicing the stock. At the same time, the necessary amount of insurance reserves is decreasing, as transport outages have significantly been reduced. This creates a strong competitive environment that maintains a relatively stable pricing environment. The demands on stock levels have been declining with the increasing demands on information related to the movement of all commodities. Globalization has thus required the creation of uniform information platforms that interconnect individual national entities. The flow of information itself makes it possible to prepare the product for national markets with different specifics, which in conjunction with the transport systems limiting the impact of long distances contributes to the global supply of even goods with limited durability. Another breakthrough on the supply side of the economy has been caused by electronic banking, which opened the global market of mail order services to households.

At the same time, one of the basic economic principles, namely the economies of scale cannot be neglected. Technical preconditions enable companies to produce for the global market, seriality is thus increasing, unit development costs and other fixed items are decreasing. Thus, the principle that production uses the cheapest global sources and the cheapest labour force globally is applied in globalization. The overall result of technical preconditions is the growth in the aggregate supply. 
Institutional preconditions also primarily affect the aggregate supply. Liberalization of mutual trade leads to the removal of tariff (tariffs, quotas) and non-tariff trade barriers (technical, safety, hygienic standards), which is reflected in the growth of aggregate supply. Today, household consumption expenditures are diversified on goods from around the world. Even basic needs are no longer met from domestic sources, but the entire consumption is globalized. In terms of investment, the liberalization of capital flows is essential. Investment growth is, among others, the result of technology transfer. Liberalization has enabled the transfer of even the most modern practices. Without the movement of funds, this trend would be considerably limited. According to [6], business internationalisation takes place as a result of trade liberalization. Internationalisation is associated with growing competition leading to increased efficiency and associated competitiveness on a global scale, as well as easier dissemination of technology, knowledge, and information. All this together supports further economic growth.

Economic preconditions associated mainly with the emergence of transnational corporations (TNCs) are the last one of the preconditions affecting the aggregate supply. TNCs build new production capacities, while taking over the existing ones where they rationalize and streamline the production process. The downside of this process is the trend of possible competition elimination and the subsequent transfer of production to more costeffective conditions. Globalization thus creates conditions for global production, with global companies making intensive use of these favourable conditions. The strength of TNCs is in the huge amount of capital they have at their disposal, which subsequently may be reflected in the use of non-economic pressures. At the same time, a considerable amount of capital makes it possible to concentrate resources on further research and development, which is another factor affecting the aggregate supply. Another problem lies in the structural changes in foreign trade in connection with the activities of transnational chains. While the economic theory is mainly concerned with trading in final products, the emergence of global value chains results not only in an increase in the volume of international trade, but especially in a change in its structure in favour of intermediate products (i.e. raw materials, components and goods in progress). At present, intermediate products account for about $60 \%$ of world non-fuel imports [13].

On the demand side of the economy, economic factors associated with the consequences of globalization play an important role, ultimately leading to changes in consumption, private investment, government purchases and foreign trade [2]. Stable and long-standing economic growth thus provokes waves of consumer optimism, which are reflected in the growth of household consumption expenditures. The growth in the population number associated with the growth of household wealth has a similar positive effect. Investors' positive expectations concerning the return on investment affect the growth of private investment. The concerns about investors going abroad are forcing many national governments to adjust the tax burden of companies and to introduce various investment incentives. At the same time, a growing economy is stimulating the growth in government purchases and transfers. Foreign trade plays an important role in globalization as well. According to Rojíček [13] and Urban [14] the current phase of globalization is associated with the dynamics of high growth in world trade and foreign investment.

All of the above preconditions of globalization and its consequences altogether have led to a significant long-term growth in aggregate demand and aggregate supply, which has ultimately been reflected in the growth of real output and employment accompanied by rising price levels, see Fig. $1 \mathrm{~b}$.

The interconnection of preconditions of globalization and factors, the AS-AD model and subsequent effects on the real economy are shown in Figure 2. This figure shows the preconditions of globalization and its consequences, which first affect the immediate goals, i.e. the stimulation of aggregate supply and aggregate demand. Subsequently, the regulation 
of aggregate supply and demand aims to meet the ultimate goals of the economic policy, which the real product growth, sufficient employment and stable price levels are.

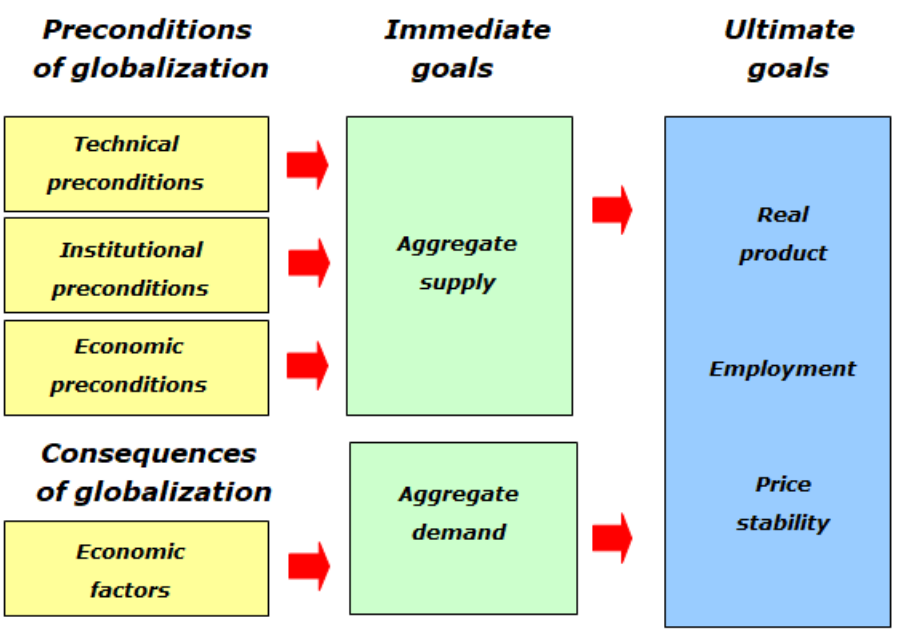

Fig. 2. Globalization, immediate goals and ultimate goals of economic policy.

Source: own based

\section{Analysis of the COVID effects on individual globalization processes}

The current global spread of the COVID 19 coronavirus epidemic can undeniably be seen as a negative consequence of globalization, as a manifestation of the close interaction of all world entities. Let us start by analysing selected effects of COVID 19 on the supply side of the economy.

In terms of technical preconditions, there has been a considerable increase in costs associated with the transport of goods, namely for a number of reasons. A marked increase in the number of sick and hospitalized workers and the necessary health checks related to the subsequent quarantine have led to a decrease in the workforce. In shift operation, individual shift groups have had to be reorganized. Health checks at borders have contributed to delays in product flows between individual countries, which in many cases has meant the end of the "just in time" system, accompanied by the need to increase production stock levels. The utilization of individual means of transport has been severely destabilized, some types of passenger and freight transport temporarily ended, for example, air transport completely collapsed.

The area of institutional preconditions has also been adversely affected by the COVID 19 epidemic. State interventionism has penetrated the liberalized global environment. In an effort to reduce health risks, individual national governments have introduced non-tariff barriers to international trade in the form of stricter health, hygienic and safety standards. The internationalisation of business was completely paralyzed due to the closure of national borders. In connection with the institutional preconditions of globalization, it is necessary to emphasise that even before the beginning of the global COVID 19 epidemic, this area was adversely affected by customs issues among the USA, the European Union and China. Although these problems have temporarily been marginalized, the spread of the COVID 19 epidemic has provided new stimuli to reassess the existing development of the liberalized world economy. Although globalization processes are associated with the pursuit of the lowest possible costs, the COVID 19 epidemic has shown that there are a number of 
strategic sectors subject to nationwide security interests where economic factors are not a priority. Individual national governments and the entire society have recognized the necessity of domestic production in the pharmaceutical industry, of medical devices and in other areas. In connection with government purchases of goods, the government must reassess expenditures on strategic reserves, which are politically uninteresting. However, the support of domestic production and the effort to achieve economic self-sufficiency go against liberalization trends.

In terms of economic preconditions, in the environment of a globalized economy, national governments are forced to seek consensus with many interest groups, while their real impact on the budget is minimal. Although political parties still formally define their position on the right-left scale, their ideological foundations and voters' preferences have a limited impact on their behaviour in the government [15]. However, the coronavirus epidemic has temporarily weakened the power of individual interest groups. Transnational corporations may be an example, as their influence on governments through lobbying or financing election campaigns is ineffective at the time of the closure of national economies. Transnational corporations are thus losing political leverages in their efforts to influence individual governments. The fact that the newly set or introduced safety standards in individual countries completely reassess maps of cost-effective areas is another factor of the economic preconditions affected by COVID 19.

In terms of analysing the demand side of the economy, it can be assumed that the COVID 19 epidemic significantly affected all components of aggregate demand in a negative way, i.e. consumption, investment, government purchases and foreign trade. Household consumption expenditures have adversely been affected by the declining disposable income and a decline in their wealth, as many workers have either been dismissed or are at risk of redundancies in the near future. There has been a reduction in some employees' working duties accompanied by a reduction in their wages. The coronavirus epidemic has also claimed hundreds of thousands of human lives. All of these and other facts have contributed to the factor of consumer pessimism. A similar situation occurred on the side of corporate capital expenditures, where the investors' strong negative expectations have caused a slow-down of planned investments even though the central banks have been trying hard to overcome the negative development on the investment side using loose monetary policies. Over the past period, the area of government purchases has been characterized by a countercyclical expansionary fiscal policy consisting in both reduction in or temporary suspension of or exemption from taxes, social and health insurance contributions, and the growth of government spending through various support programs. Although this policy, accompanied by the proposed or approved state budget deficits, has an effect on the growth in aggregate demand, its extent is not enough to compensate for the decline in consumption, investments and foreign trade described above. The lockdown of national economies has completely paralyzed or considerably reduced international trade, which is one of the main determinants of economic growth in many economies. As exports declined faster than operational imports, the overall result of net exports was negative. The empirical data of the selected countries of the European Union for the 2nd quarter of 2020 show that the above-mentioned analysis of aggregate demand was correct, see Table 1.

If we summarise the above-mentioned analysis, one can conclude that the impact of COVID 19 on the globalization processes will be reflected in a decline in aggregate supply and aggregate demand. Regardless of the proportions of their mutual drop, the real product will decrease. In the event that the decline in aggregate supply exceeds the decline in aggregate demand, the price levels will increase. This result is also confirmed by the empirical data from Table 1. 
Table 1. Macroeconomic data of the selected countries of the European Union.

\begin{tabular}{|c|c|c|c|c|c|c|c|c|c|c|}
\hline & GDP & c & G & 1 & GDP & c & G & 1 & $\begin{array}{c}\text { Inflation rates }(\%) \\
\text { Annual rate }\end{array}$ & $\begin{array}{l}\text { Growth rates } \\
\text { of employment } \\
\text { in persons }\end{array}$ \\
\hline & $a / a-4$ & $Q / Q-4$ & $Q / a-4$ & $a / a-4$ & $a / a-1$ & $Q / Q-1$ & $\mathrm{Q} / \mathrm{Q}-1$ & $\mathrm{Q} / \mathrm{Q}-1$ & Aug 2020 & $a / a-1$ \\
\hline Euro area & $-14,7$ & $-16,0$ & $-2,5$ & $-20,9$ & $-11,8$ & $-12,4$ & $-2,6$ & $-17,0$ & $-0,2$ & $-2,9$ \\
\hline EU27 & $-13,9$ & $-15,2$ & $-2,1$ & $-19,0$ & $-11,4$ & $-12,0$ & $-2,4$ & $-15,4$ & 0,4 & $-2,7$ \\
\hline Czechia & $-11,0$ & $-7,3$ & 2,1 & $-4,6$ & $-8,7$ & $-6,3$ & $-1,5$ & 0,9 & 3,5 & $-1,4$ \\
\hline Slovakia & $-12,2$ & $-4,0$ (e) & $-10,4$ (e) & $-14,6(\mathrm{e})$ & $-8,3$ & - & $\cdot$ & $\cdot$ & 1,4 & $-1,1$ \\
\hline Germany & $-11,3$ & $-13,0(p)$ & $3,8(p)$ & $-8,3(p)$ & $-9,7$ & $-10,9(p)$ & $1,5(p)$ & $-7,9(p)$ & $-0,1$ & $-1,4$ \\
\hline Austria & $-12,9$ & $-15,4$ & 1,9 & $-11,2$ & $-10,4$ & $-11,5$ & 1,0 & $-7,6$ & 1,4 & $-4,1$ \\
\hline Poland & $-7,9$ & $-11,0$ & 4,3 & $-11,1$ & $-8,9$ & $-10,8$ & 0,9 & $-11,4$ & 3,7 & $-1,2$ \\
\hline Hungary & $-13,5$ & $-8,1(p)$ & $-2,7(p)$ & $-13,5(p)$ & $-14,5$ & $-11,3$ & $-1,5$ & $-13,8$ & 4,0 & $-5,3$ \\
\hline France & $-18,9$ & $-16,6$ & $-12,1$ & $-21,5$ & $-13,8$ & $-11,8$ & $-10,3$ & $-14,9$ & 0,2 & $-2,6$ \\
\hline Italy & $-17,7$ & $-17,6$ & $-2,4$ & $-22,1$ & $-12,8$ & $-11,3$ & $-0,9$ & $-14,9$ & $-0,5$ & $-2,5$ \\
\hline
\end{tabular}

Source: own processing [16-20]

\section{Conclusion}

The globalized economy has entered a standard downturn phase of the economic cycle. This trend was already evident from most macroeconomic data for the last quarter of 2019. However, the global COVID 19 epidemic not only accelerated this decline, but also changed its nature. If, at the beginning of 2020, the decline was driven by a global decline in investment, namely due to the existence of significant business uncertainties caused by, among others, customs disputes among the USA, Europe and China, the current economic downturn is caused by a decline in aggregate supply accompanied by inflationary pressures.

The autumn of this year shows that economic problems are escalating further. The business environment remains very unstable. Within the coming second coronavirus wave, households and businesses expect a gradual re-closure of borders, which will disrupt established global relationships again. The COVID 19 epidemic is thus a great test for national economies, but also a touchstone of globalization. Many economies will be forced to rethink some globalization trends in the context of national safety when excessive focus on cost aspects has led to a loss of national self-sufficiency in the defined strategic areas.

In times of recession, the role of governments and central banks, which must pursue counter-cyclical economic policies, is always growing. Fiscal and monetary policies must be expansionary in the short term, i.e. they must affect the growth of aggregate demand. If the economic policy is not to be counterproductive in the long run, the future growth in aggregate demand must be accompanied by an adequate growth in aggregate supply. This means that governments must focus their attention not only on the demand side of the economy, which they are currently doing, but also on its supply side.

This article was created within the project SGS-2018-042 "The Application of Quantitative Methods in Economics" at the Faculty of Economics of the West Bohemia University in Pilsen.

\section{References}

1. Mankiw, G.N. (2001). Principles of Economics. Fort Worth: Harcourt College Publishers.

2. Samuelson, P.A., Nordhaus, W.D. (2013). Ekonomie. (19. vyd.). Praha: NS Svoboda.

3. Frait, J., Zedníček, R. (1995). Makroekonomie pro základni a středně pokročilý kurs. Ostrava: Mc PROM.

4. Mandel, M. (1998). Inflation and monetary targeting with exogenous shocks. Finance a úvěr, 48(4), 237-251. 
5. Breinek, P. (2005). Processes of globalization in the world economy. Politická ekonomie, 53(6), 826-841.

6. Kunešová, H., Kocourek, A., Bednářová, P., Cihelková, E., Nový, M. (2014). Světová ekonomika. Nové jevy a perspektivy. (3. vyd.). Praha: C. H. Beck.

7. Žídek, L. (2009). Globalization and the world economy. Politická ekonomie, 57(5), 622-643.

8. Jeníček, V. (2012). Globalisation - content, dynamics. Agricultural EconomicsZemědělska ekonomika, 58(3), 127-134.

9. Kocourek, A., Bednářová, P., Laboutková, Š. (2013). The linkages between human development and economic, social, and political dimension of globalization. $E \& M$ Ekonomie a Management, 16(2), 10-21.

10. Hejduková, P., Kureková, L. (2016). The globalized world and migrants: impacts of healthcare markets. In T. Kliestik (Eds.), Globalization and its socio-economic consequences, $16^{\text {th }}$ International Scientific Conference Proceedings (pp. 628-635). Žilina: University of Žilina.

11. Woodward, D., Drager, N., Beaglehole, R., Lipson, D. (2001). Globalization and health: a framework for analysis and action. Bulletin of the World Health Organization 2001, 79(9), 875-881.

12. Janáček, K., Janáčková S. (2018). The threat of secular stagnation. Politická ekonomie, 66(1), $116-135$.

13. Rojíček, M. (2012). Impact of globalisation on the functioning of international trade. Politická ekonomie, 60(2), 187-207.

14. Urban, J. (2015). Teorie národního hospodářství. Praha: Wolters Kluwer.

15. Roženský, V. (2014). The effects of economic, social and institutional factors on social expenditure levels. Politická ekonomie, 62(3), 383-399.

16. EUROSTAT (2020, September 8). GDP main aggregates and employment estimates for the second quarter of 2020. News Releases: euroindicators. https://ec.europa.eu/eurostat/documents/2995521/10545471/2-08092020-APEN.pdf/43764613-3547-2e40-7a24-d20c30a20f64

17. ČSÚ (2020). Soukromé výdaje na konečnou spotřebu-objemy (čtvrtletně) http://apl.czso.cz/pll/eutab/html.h?ptabkod=teina021

18. ČSÚ (2020). Vládní výdaje na konečnou spotřebu-objemy (čtvrtletně). http://apl.czso.cz/pll/eutab/html.h?ptabkod=teina031

19. ČSÚ (2020). Tvorba hrubého fixního kapitálu - objemy (čtvrtletně). http://apl.czso.cz/pll/eutab/html.h?ptabkod=teina041

20. EUROSTAT (2020, September 17). Annual inflation down to $-0,2 \%$ in the euro area. News Releases : euroindicators. https://ec.europa.eu/eurostat/documents/2995521/10568619/2-17092020-APEN.pdf/2eef0072-7156-7bd6-69f2-a8326ea63b82 